\title{
Editorial
}

\section{Review article on Calotropis (Wara): Is it a miracle shrub or just a plant?}

\author{
PD Abeysinghe \\ Professor in Botany, Department of Botany, Faculty of Science, University of Ruhuna, Matara, Sri Lanka
}

Apocynaceae Juss. (The Angiosperm Phylogeny Group, 2016) commonly called as the dogbane family, comprises 357 genera and about 5100 species (Nazar et al., 2013) of flowering plants including herbaceous or shrubby climbers (Wong et al., 2013; Chan et al., 2016: Lu et al., 2014). The Calotropis (Wara, hela-wara in Sinhala and errukalai, manakkovi, mannakovi, urkkovi in Tamil) which is a small genus belongs to this family consisting of two species, Calotropis gigantea (L.) R. Br. and $C$. procera (Aiton) Dryand. Calotropis is a succulent and xerophytic shrub or small laticiferous tree up to $2.5 \mathrm{~m}$, commonly known as "milkweed" or "Crown flower" (Kumar et al., 2011; Hindi, 2013; Wong et al., 2013; Muriira et al., 2015; Moustafa and Sarah, 2017). The stem usually simple and branched at the base, woody covered with a corky bark, leaves simple, opposite, sub-sessile, white and purplecolored flowers and not scented (Sharma, 2011; Joseph et al., 2013). Inflorescence is a dense, multiflowered, umbellate cyme, highly cross-pollinated through insects such as monarch butterflies, simple, follicle fruit (Endress et al., 2007; Joseph et al., 2013). Following figure shows the purple and white colored flowers and follicle fruit of Calotropis found in Sri Lanka. Calotropis species are most diverse in tropical and subtropical parts of Asia and South East Asia (Bangladesh, Cambodia, Burma, China, India, Indonesia, Malaysia, Pakistan, Philippines, Sri Lanka and Thailand) and extend into temperate areas (Nasser et al., 2012; Nazar et al., 2013). Calotropis is a versatile tree used for different purposes. The importance of Calotropis can be explained: (a) uses of the plant in traditional medicine (b) research performed on the isolation of compounds and their scientific value (c) commercial values of the plant. (a) Uses of the plant in traditional medicine

Calotropis is planted as a medicinal plant in Malaysia (Wong et al., 2013). Not only in Sri Lanka (Solohokara et al., 2015) but also in other countries, like India (Meena et al., 2010; Kumar et al., 2010a; Gaur et al., 2013; Joseph et al., 2013; Harsimran and Shikha, 2015) Bangladesh (Haque et al., 2012) almost all parts of the plant (leaf, bark, root, latex, flower etc.) are used for treatment of a number of diseases or cure several illnesses such as toothache, caries, ear ache, stings, sprain, ringworm, syphilis, anxiety, rheumatism, pain, epilepsy, leprosy, diarrhoea, skin diseases, boils and sores, ulcers, piles, malaria, rheumatism, mental and dental disorders and several other ailments of spleen and liver (Sharma and Sharma, 2000; Setty et al., 2007; Bharti et al., 2010; Singh, 2002; Gaur et al., 2013; Aarti, 2014). Analgesic activity, pro-coagulant activity, wound healing activities have been observed (Qari, 2008; Kumar et al., 2010b; Kumar et al., 2011; Meena et al., 2010; Pandey et al., 2016; Gaur et al., 2013; Joseph et al, 2013; Aarti, 2014). The powdered flowers are given for coughs, colds and asthma (Gaur et al., 2013). The crushed and warmed leaves are applied on burns, headaches and rheumatic pains, used as a tincture for intermittent fever, used as a tonic, used as a purgative in small doses, used as an emetic in larger doses, (Gaur et al., 2013, Chitme et al., 2005; Saratha et al., 2009).

In Bangladesh by folk medicinal practitioners use leaves for treatment of high blood sugar and pain. Research carried out by Haque et al., (2012) strongly showed that of leaves of $C$. gigantea is a potential source of obtaining newer anti-hyperglycemic and anti-nociceptive drugs for treatment of pain and high blood sugar levels in diabetic patients. The roots of

*corresponding author: pushpa@bot.ruh.ac.lk, iD https://orcid.org/0000-0002-2026-3014

This article is published under the Creative Commons CC-BY-ND License (http://creativecommons.org/licenses/by-nd/4.0/). This license permits commercial and non-commercial reuse, distribution, and reproduction in any medium, provided the original work is not changed in any way and is properly cited. 
the plant is reported to have properties of pregnancy interceptive (Srivastava et al., 2007).

\section{(b) Research performed on the isolation of active compounds and their scientific value}

Antimicrobial activity of latex against pathogenic microorganisms (Kumar et al., 2010a; Kumar et al., 2011; Kovendan et al., 2012; Gaur et al., 2013). In vitro antimicrobial activity of the aqueous extract of the $C$. gigantea against Staphylococcus aureus, Escherichia coli, Bacillus cereus, B. subtilis, Pseudomonas aeruginosa, Micrococcus luteus, Klebsiella pneumonia, Salmonella typhi and Micrococcus luteus strains has been conducted and the extract has been shown significant effect on the tested organisms (Kumar et al., 2010a, b, c; Aarti, 2014). The antifungal activity of $C$. gigantea was activity (Sharma et al., 2016), anti-oxidant activities (Sharma et al., 2011; Elakkiya and Prasanna, 2012; Aarti, 2014; Kazemipour et al., 2015), pro-coagulant activity (Gaur et al., 2013) have been reported. Antivenom activity of Calotropis gigantea extract was evaluated against Vipera russelli snake venom. The roots of the plant are crushed and applied over the snake bitten area (Jain et al., 2011; Gaur et al., 2013; Aarti, 2014). The medicinal properties of this plant represents as a valuable source of medicinal compounds. In last few decades, Calotropis has been extensively studied for its medicinal properties with the aid of advanced scientific techniques. As a result of, a variety of bioactive compounds has been isolated from different parts of the plant and has analysed pharmacologically (Meena et al., 2010; Sharma et al., 2016). The latex can also be applied over the dental area for any tooth related problems, over the body to cure nerve disorders (Gaur et al.,

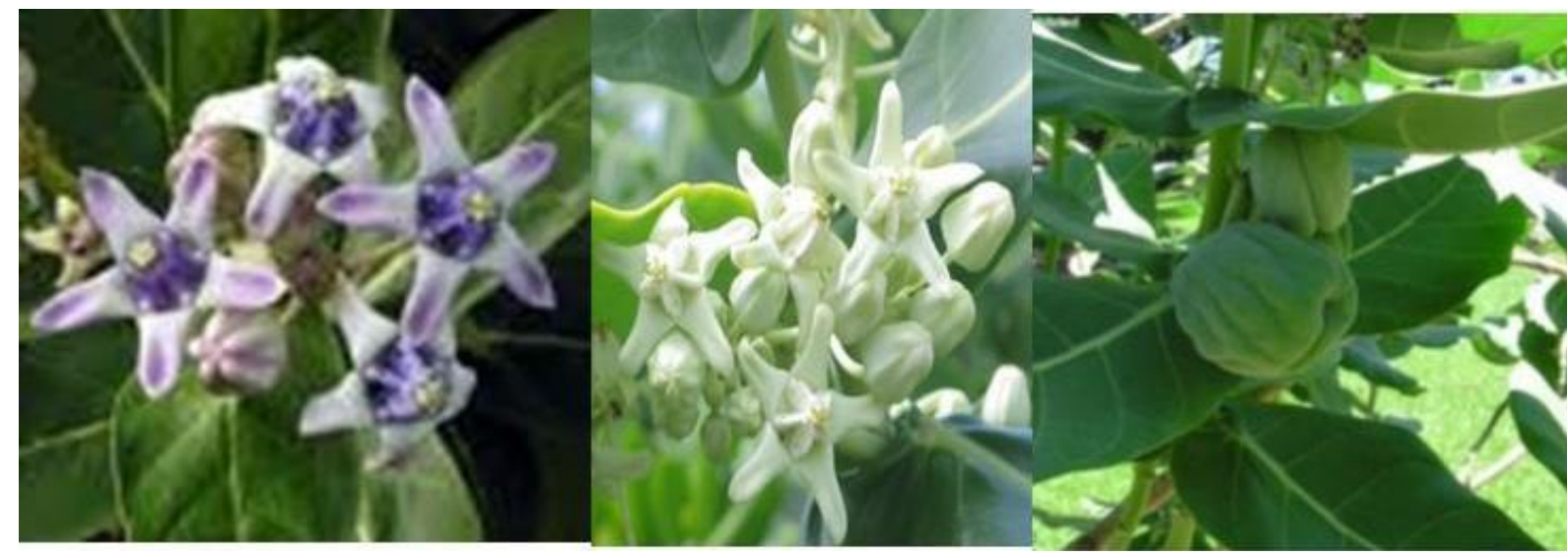

Figure 1: Purple coloured flowers, white coloured flowers and fruit of $C$. gigantea

also reported in some studies and it provides an important option for the biological control of Fusarium mangiferae, a plant pathogenic fungus that causes serious threat in mango cultivation in various countries (Usha et al., 2009). Antifungal activity and lethal effect of Aspergillus terreus, A. flavus, A. niger, A. fumigates have been studied (Qari, 2008). C. gigantea is scientifically reported for its antiCandida activity (Candida albicans, C. parapsilosis, C. tropicalis and C. krusei - Aarti, 2014). Latex of Calotropis can be applied over the infected area. This could be used in swellings or rat bitten areas or other disorder infected area.

Cytotoxic effect on several human cancer cell lines (Ramos et al., 2006; Bekhit et., 2008; Kumar et al., 2011; Quazi et al, 2013; Aarti, 2014), chromosomal aberrations and genotoxicity of Allium cepa, Vicia faba (Qari, 2008), antipyretic activity (Gaur et al., 2013; Aarti, 2014; Pandey et al., 2016), insecticidal
2013). Latex contains alkaloids, tannins, gum, sugars, starch, resins and protein osmotin and lupeol (Aarti, 2014). The other plant parts contain cardiac glycosides, flavonoids, phenolic compounds, and terpenes/terpenoides alkaloids, tannins, saponins, flavnoid, steriods, terpeniods reducing sugars resins osmotin and etc. (Khan and Malik, 1989; de Freitas et al., 2011; Aarti, 2014; Mueen et al., 2015). Cardiac glycosides which is present in Calotropis have also proven anticancer properties (Van Quaquebek et al., 2005;), increased heart beats and heart contractions, increased the motility of smooth muscles, relaxing effect on the contracted skeletal muscles (Moustafa and Sarah, 2017).

Mosquitocidal, larvicidal and pupicidal properties of medically important mosquito vector species; Anopheles stephensi, Aedes aegypti, and Culex quinquefasciatus have been studied (Neraliya and 
Srivastava, 1996; Moustafa and Sarah, 2017). A study revealed the ethanol extract of leaf of $C$. gigantea is an ideal eco-friendly approach for the control of vector (Kovendan et al., 2012). A decoction of leaf along with soap is an effective remedy for white ants (Ranade and Acharya, 2014). Stem of this plant possess hepato-protective effects as demonstrated by protection of liver of rats against carbon tetrachloride induced liver injury, effects against hepato-carcinogenesis without any harmful effects in treated animals (Wong et al., 2013). Toxic effect of Calotropis on the heart and testis of male albino rats has been tested, proven high toxicity and recommended the use of Calotropis as rodent control without leaving harmful chemical traces (Moustafa and Sarah, 2017).

\section{(c) Commercial values of the plant}

Due to its potential economic importance, Calotropis has been introduced to the Pacific Islands, Australia, as well as to Central and South America as an ornamental plant (Maji et al., 2013; Hindi, 2013; Joseph et al, 2013, Payal and Sharma, 2015). Calotropis stem and seed coat produces fine, white, silky, durable, strong, cylindrical, flexible and highquality fibre which has created great interest in many countries for industrial applications; useful for making ropes, carpets, fishing nets, cheap cots, gunny bags, bow strings, in the manufacture of paper, pulp, duplicating stencils, sewing threads (Gaur et al., 2013; Muriira et al., 2015; Akhtar et al., 2014; Payal and Sharma, 2015; Priya et al., 2015). Strong inner bark fibres produce a binding material and are processed into fabrics. Due to presence of high quality fibre, fibre gene $C p T I P 1$, isolated from the wild plant Calotropis and transferred into cotton variety NIAB-846 for one generation (Akhtar et al., 2014). The white, strong and silky floss which is from the fruit (seed capsules) is used as an inferior stuffing material in mattresses and pillows as well as for weaving into a strong cloths, shawls, handkerchiefs, packing material since it is too short and too light for spinning (Ranade and Acharya, 2014; Payal and Sharma, 2015). The floss may also substitute cotton wool for surgical purposes (Akhtar et al., 2014).

The seed oil can be used for soap, paint and making varnish and oil cake is used as manure (Ranade and Acharya, 2014). In Thailand, the flowers are used in wedding ceremonies, various floral arrangements in temples and in rosaries (Gaur et al., 201). Ruminant (sheep, goats, and camels) are fed with other feeds which are mixed with chopped leaves of Calotropis (Payal and Sharma, 2015). Calotropis is a good source of green manure which can help to improve soil water conditions and also acts as a soil binder and mulching (Gaur et al., 2013; Payal and Sharma, 2015; dos Santos et al., 2017; Fanish, 2017). Wood is used in making charcoal and cooking fuel (Gaur et al., 2013; Nasser et al, 2012; Hindi, 2013).

Plants often escape from cultivation, especially when growing on sandy soils (near to sea beaches and coastal areas). This precious plant is able to propagate and thrive in harsh conditions of heat, drought and poor soils, high salinity and water logging wastes, fallow lands, rubbish heaps, roadsides, sand dunes and arable lands in different environments (Meena et al., 2010; Hindi, 2013). Moreover, this plant has a high level of regeneration potential and could be harvested up to 4 times a year. Calotropis often self-sows freely on overgrazed land and has been used as an indicator of exhausted soil. Due to its ability to accumulate heavy metals, natural elements (Uranium) from different soils and an abandoned mining site, Calotropis has several ecological roles: serves as natural phytoremediation, improves the quality of soil, rehabilitates abandoned and exhausted lands and brings back life once again (Moustafa and Sarah, 2017).

The liquid latex, a rubber-like product can be used as a renewable source of valuable hydrocarbons and intermediate energy resources which may be utilized to convert into diesel substitutes (Erdman and Erdman 1981; Shilpkar, 2007: Moustafa and Sarah, 2017). Due to free from NOx gases, $\mathrm{SO}_{2}$ and Suspended Particulate Matter (SPM) and high cetane value, the bio-diesel derived from Calotropis may be a good source of renewable energy (Payal and Sharma, 2015). Therefore, Calotropis may be a potential plant for bioenergy and biofuel production in these areas where Calotropis grow. (Payal and Sharma, 2015; Moustafa and Sarah, 2017).

\section{Future areas of the research}

As a conclusion, scientists, relevant authorities and other stakeholders have not paid attention on this wonderful and amazing plant present in Sri Lanka. Therefore, further researches are necessary to elucidate the phytochemical and pharmacological aspects of this plant to look forward the therapeutic aspects, development of new drugs from Calotropis for the control and combat the various diseases. Because of its high adaptability to severe environments, invading abilities, researchers consider this valuable plant as a weed or an invasive plant and are looking for controlling strategies. Instead of destroying, considering the numerous benefits and 
products of the plant in different facets (eco-friendly solutions to pollution, to fulfil the demand of fibre for textile industry, energy limitation and habitat degradation problems, etc.), this valuable and fastgrowing tree species can be utilized to overcome these problems.

\section{References}

Aarti, C. (2014) A review on pharmacological and biological properties of Calotropis gigantea. International Journal of Recent Science Research. 5(4), 716-719.

Akhtar, S., Shahid, A. A., Rao, A.Q., Bajwa, K.S., Muzaffar, A., Lateef, A., Husnain, T. (2014) Genetic effects of Calotropis procera CpTIP1 gene on fiber quality in cotton (Gossypium hirsutum). Advvances in life Sciences. 1(4): 223-230.

Alam, M. A., Habib, M.R,, Nikkon, R., Rahman, M., Karim, M.R., (2008) Antimicrobial activity of akanda (Calotropis gigantean L.) on some pathogenic bacteria, bacteria. Bangladesh Journal of Science Industrial Research. 43:397-404.

Basu, A., Chaudhuri, A.K., (1991) Preliminary studies on the anti-inflammatory and analgesic activities of Calotropis procera root extract. Journal of Ethnopharmacology. 30(3):319-324.

Bekhit, A.A., Ashour, H.M.A., Ghany, Y.S.A., Bekhit, A.E.D.A., Baraka, A., (2008) Synthesis and biological evaluation of some thiazolyl and thiadiazolyl derivatives of 1H-pyrazole as antiinflammatory antimicrobial agents. European Journal of medicinal chemistry. 43 (3):456-463.

Bharti, S., Wahane, V.D., Kumar, V. L., (2010) Protective effect of Calotropis procera latex extracts on experimentally induced gastric ulcers in rat. Journal of Ethnopharmacology. 127:440-444.

Chan, E.W.C., Wong, S.K., Chan, H.T., (2016) Apocynaceae species with antiproliferative and/or antiplasmodial properties: a review of ten genera. Journal of Integrated Medicine. 14(4):269-284.

Chitme, H.R., Chandra, R., Kaushik, S., (2005) Evaluation of antipyretic activity of Calotropis gigantea (Asclepiadaceae) in experimental animals. Phytotherapy Research. 19:454-456.

de Freitas, C.D.T., de Souza, Lopes. J.L., Beltramini, L.K., de Oliveira, R.S.B., Oliveira, J.T.A., Ramos, M.V., (2011) Osmotin from Calotropis procera latex:
New insights into structure and antifungal properties. Biochimica et Biophysica Acta. 1808: 2501-2507

dos Santos, M.G., Souza, E.G.F., da Silva, A.F.A., Barboza, M., Soares, E.B., Lins, H.A., Júnior, A.P.B., da Silveira, L.M., Neto, F.B., (2017) Beetroot production using Calotropis procera as green manure in the Brazilian Northeast Semiarid. Australian Journal of Crop Science. 11(10):1268-1276.

Erdman, M.D., Erdman, B.A., (1981) Calotropis procera as a source of plant hydrocarbons economic Botany. 35(4): 467--472

Endress, M.E., Liede-Schumann, S., Meve, U., (2007) Advances in Apocynaceae: The enlightenment, an introduction. Annals of the Missouri Botanical Garden. 94: 259-267.

Elakkiya, P., Prasanna, G., (2012) A study on phytochemical screening and invitro antioxidant activity of Calotropis gigantea L. International Journal of PharmTech Research. 4(4):1428-1431.

Fanish, S.A., (2017) Impact of green manure incorporation on soil properties and crop growth environment: A Review. World Journal of Agricultural Sciences 13 (3):122-132.

Gaur, L.B., Bornare, S.S., Chavan, A.S., Ram, M., Singh, S.P., Kumar, G.S., (2013) Biological activities and medicinal properties of Madar (Calotropis gigantea R.Br.) PunarnaV. 1:11-19.

Haque, M., Choudhury, S., Hossain, S., Haque, A., Debnath, K., Hossain, S., Mou, S.M., Malek, I., Rahmatullah, M., (2012) Evaluation of antihyperglycemic and anti-nociceptive properties of leaves of Calotropis gigantea R.Br. (Asclepiadaceae) - a medicinal plant of Bangladesh. Advance Natural and Applied Science. 6(8):1508-1514.

Harsimran, R.K., Shikha, S., (2015) Phytochemical investigations and anatomical study of two species of Calotropis from Chandigarh. Int. Journal of Pharm. Science Research. 6(4):1452-1459.

Hindi, S.S.Z., (2013) Calotropis procera: The Miracle Shrub in the Arabian Peninsula. International Journal of Science and Engineering Investigations. 2:48-57.

Jain, A., Katewa, S.S., Sharma S.K, Galav, P., Jain, V., (2011) Snakelore and indigenous snakebite remedies practised by some tribals of Rajasthan. 
Indian Journal of Traditional Knowledge. 10(2):258268.

Joseph, B., George, J., Jeevitha, M.V., Charles, S., (2013) Pharmacological and biological overview on Calotropis gigantea: a comprehensive review. International Research Journal of Pharmacological Applied Science. 3(5):219-223.

Kazemipour, N., Nikbin, M., Davarimanesh, A., Sepehrimanesh, M., (2015) Antioxidant activity and mineral element contents of Calotropis procera from Iran: A traditional medicinal plant in Middle East. Compounds in Clincal Pathology. 24:1147-1150.

Khan. Q, Malik, A., (1989) A steroid from Calotropis procera. Phytochemistry. 28:2859-2861.

Kovendan, K., Murugan, K., Kumar, K.P., Panneerselvam, C., Kumar, P.M., Amerasan, D., Subramaniam, J., Vincent, S., (2012) Mosquitocidal properties of Calotropis gigantea (Family: Asclepiadaceae) leaf extract and bacterial insecticide, Bacillus thuringiensis, against the mosquito vectors. Parasitology Research. 111:531-544.

Kumar, G., Karthik, L., Rao, K.V.B., (2010a) Antimicrobial Activity of Latex of Calotropis gigantea Against Pathogenic Microorganisms - An in vitro study. International Journal of Pharmaceutical Sciences Review and Research. Int. Research Journal of Pharmacy Applied Science. 3:155-163.

Kumar, G., Karthik, L., Rao, K.V.B., (2010b) In vitro anti-Candida activity of Calotropis gigantea against clinical isolates of Candida, Journal of Pharmacy Research. 3:539-542.

Lu, Y., Khoo, T.J., Wiart, C., (2014) The Genus Melodinus (Apocynaceae): Chemical and Pharmacological Perspectives. Pharmacy. 5:540-550.

Maji, S., Mehrotra, R., Mehrotra, S., (2013) Extraction of high quality cellulose from the stem of Calotropis procera. South Asian Journal Experimental Biology. 3(3):113-118.

Meena, A.K., Yadav, A.K., Niranjan, U.S., Singh, B., Nagariya, A.K., Sharma, K., Gaurav, A., Sharma, S., Rao, M.M., (2010) A review on Calotropis procera Linn and its ethnobotany, Phytochemical, Pharmacological Profile. Drug Invention Today. 2(2):85-190.

Moustafa, A.R.A., Sarah., S.Q., (2017) Population Ecology and Economic Importance of Calotropis procera as an exotic medicinal plant. Journal of Ecology and Natural Resources. 1(1):1-11.

Mueen, A., Rana, A., Dixit, V., (2005) Calotropis species (Asclepediaceae), a comprehensive review. Pharmacogn Mag. 1:48-52.

Muriira, N.G., Xu, W., Muchugi, A., Xu, J., Liu, A., (2015) De novo sequencing and assembly analysis of transcriptome in the Sodom apple (Calotropis gigantea). BMC Genomics 16:723. DOI 10.1186/s12864-015-1908-3.

Nazar, N., Goyder, D.J., Clarkson, J.J., Mahmood, T., Chase, M.W., (2013) The taxonomy and systematics of Apocynaceae: where we stand in 2012. Botanical Journal of the Linnean Society, 2013. 171, 482-490.

Nasser, R.A., Al-Mefarrej, H.A., Khan, P.R., Alhafta, K.H., (2012) Technological properties of Calotropis procera (AIT) wood and its relation to utilizations. American-Eurasian Journal of Agriculture Environmental Science. 12 (1):05-16.

Neraliya. S., Srivastava, U.S., (1996) Effect of plant extracts on post-embryonic development of the mosquito Culex quinquefasciatus. Journal of Advanced Zoology. 17:54 - 8 .

Pandey, A., Swarnkar, V., Pandey, T., Srivastava, P., Kanojiya, S., Mishra, D.K., Tripathi, V., (2016) Transcriptome and Metabolite analysis reveal candidate genes of the cardiac glycoside biosynthetic pathway from Calotropis procera. Scientific Reports. 6:34464 DOI: 10.1038/srep34464.

Payal, C., Sharma, R.A., (2015) An overview on giant milkweed (Calotropis procera (Ait.) Ait. f.). Journal of Plant Sciences. 3(1-1): 19-23.

Priya, T.M., Manimekalai, V., Ravichandran, P., (2015) Intra specific genetic diversity studies on Calotropis gigantea (1) R. Br. - using RAPD markers. European Journal of Biotechnology and Bioscience. 3(4):7-9.

Qari, S.H., (2008) Molecular and biochemical evaluation of genetic effect of Calotropis procera. (Ait.) Latex on Aspergillus terreus (Thom). Indian Journal of Experimental Biology. 46:725-730.

Quazi, s., Mathur, K., Arora, S., (2013) Indian Journal of Drugs, 2013, 1(2), 63-69

Ramos, M.V., Bandeira, G.P., de Freitas, C.D.T., Nogueira, N.A.P., Alencar, N.M.N., de Sousa, 
P.A.C., Carvalho, A.F.U., (2006) Latex constituents from Calotropis procera ( $\mathrm{R}$. Br.) display toxicity upon egg hatching and larvae of Aedes aegypti (Linn.). Mem Inst Oswaldo Cruz, Rio de Janeiro. 101(5): 503-510.

Ranade, A., Acharya, R., (2014) An appraisal on ethno-medicinal claims of Calotropis procera ait and Calotropis gigantea (LINN) R. Br. - Two source drugs of ayurvedic medicinal plant 'Arka'. Global Journal of Research.journal of Medicinal Plant Indigenous Medicine. 3(12):475-488.

Saratha, V., Subramanian, S., Sivakumar, S., (2009) Evaluation of wound healing potential of Calotropis gigantea latex studied on excision wounds in experimental animals, Medical and Chemistry Research. 78:451-454.

Seniya, C., Trivedia, S.S., Verma, S.K., (2011) Antibacterial efficacy and phytochemical analysis of organic solvent extracts of Calotropis gigantea. Journal of Chemistry and Pharmaceutical. Research. 3(6):330-336.

Setty, S.R., Quereshi, A.A., Viswanath, Swamy, A.H., Patil, T., Prakash, T., Prabhu, K., Veeran, Gouda, A., (2007) Hepatoprotective activity of Calotropis procera flowers against paracetamolinduced hepatic injury in rats. Fitoterapia. 78:451454.

Sharma, P., Sharma, J.D., (2000) In-vitro schizonticidal screening of Calotropis procera. Fitoterapia. 71:77-79.

Sharma, AK., Kharb, R., Kaur, R., (2011) Pharmacognostical aspects of Calotropis procera (Ait.) R. Br. International Journal of Pharma and Bio Sciences. 2(3): 480-487.

Shilpkar, P., Shah, M., Chaudhary, D.R., (2007) An alternate use of Calotropis gigantea: Biomethanation. Current science. 92: 425 - 436.

Sharma, N., Shankar, R., Gupta, N., Prakash. P., (2016) A Preliminary Phyto-Pharmacognostical evaluation of Calotropis gigantea $(\mathrm{L}$.$) R. Br. (Alarka$ or Mandara ) Root. International Journal of Ayurvedic Medicine. 7(1), 44-48

Singh, A.K., Raghubanshi, A.S., Singh, J.S., (2002) Medical ethnobotany of the tribals of Sonaghati of Sonbhadra district, Uttar Pradesh, India. Journal of Ethnopharmacology. 81:31-41.
Singh, S., Mishra, R.M., Shrivastava, M.P., (2014) Preliminary phytochemical screening of Calotropis gigantean leaf. International Journal of Scientific and Research Publications. 4(2):1-3.

Singh, V., (2012) Calotropis boon or bane? Open Journal of Stomatology. 2:149-152.

Solohokara, S.M.N.J., Jayasundera, A.C.A., Karunathilake, L.P.A., (2015) Preliminary phytochemical screening of Calotropis gigantia (vern:arka) alkaline powder (kshara) in Ayurveda. Unique Journal of Ayurvedic and Herbal Medicines. 3(5):30-32.

Srivastava, S.R., Keshri, G., Biju, Bhargavan, B., Chandan, Singh, C., Singh, M.M., (2007) Pregnancy interceptive activity of the roots of Calotropis gigantea Linn. in rats. Contraception. 75(4):318-22

The Angiosperm Phylogeny Group, (2016) An update of the angiosperm phylogeny group classification for the orders and families of flowering plants: APG IV. Botany Journal of Linn. Society. 181(1):1-20.

Usha, K., Singh, B., Praseetha, P., Deepa, N., Agarwal, D.K., Agarwal, R., Nagaraja, A., (2009) Antifungal activity of Datura stramonium, Calotropis gigantea and Azadirachta indica against Fusarium mangiferae and floral malformation in mango, European Journal of Plant Pathology. 124:637-657.

Van, Quaquebeke, E., Simon, G., André, A., Dewelle, J., El Yazidi, M., Bruyneel, F., Tuti, J., Nacoulma, O., Guissou P, Decaestecker C, Braekman JC, Kiss, R., Darro, F., (2005) Identification of a novel cardenolide ( $2^{\prime \prime}$-oxovoruscharin) from Calotropis procera and the hemi-synthesis of novel derivatives displaying potent in vitro anti-tumor activities and high in vivo tolerance: structure activity relationship analyses. Journal of Medical Chemistry. 48, 849-885.

Wong, S.K., Lim, Y.Y., Chan, E.W.C., (2013) Pharmacognosy Communications Botany, uses, phytochemistry and pharmacology of selected Apocynaceae species: A review. Pharmacology and Communications. 3(3):2-11. 